\title{
Current Practices and Improvement of Saudi Corporate Governance Framework
}

\author{
Khalid Saad Al-habshan ${ }^{1}$ \\ ${ }^{1}$ School of Law, Brunel University, UK \\ Correspondence: Khalid Saad Al-habshan, School of Law, Brunel University, UK. E-mail: \\ habshan_33@hotmail.com
}

Received: May 5, 2017

Accepted: July 11, 2017 Online Published: August 30, 2017

doi:10.5539/jpl.v10n4p81

URL: https://doi.org/10.5539/jpl.v10n4p81

\section{Overview}

The preceding article described the notions of disclosure and transparency and their purpose and importance in practice. An understanding of the requirements and elements of the practice of disclosure leads to a discussion of its benefits and advantages, as well as the consequences of a lack of transparency during financial scandals. The Saudi approach to disclosure and transparency is also examined based on the evidence given in board annual reports. This paper highlights the way the Saudi legal system evaluates corporate governance and its legal basis.

\section{Background Information about Saudi Arabia}

In 1932, King Abdul Aziz Ibn Abdul Rahman Al-Faisal Al-Saud succeeded in consolidating the kingdoms of Nejd and Hejaz to create the independent Islamic monarchy of the Kingdom of Saudi Arabia following three decades of sporadic fighting. ${ }^{1}$ Since early August 2005, Saudi Arabia's head of state has been Custodian of the Two Holy Mosques His Majesty King Abdullah Ibn Abdul Aziz Al-Saud. King Abdullah serves as president of the Council of Ministers through which the Kingdom of Saudi Arabia is administered. ${ }^{2} \mathrm{He}$ is supported by numerous ministers, including the first deputy premier (His Royal Highness Crown Prince Sultan Ibn Abdul Aziz Al-Saud) and second deputy premier (His Royal Highness Crown Prince Nayef Ibn Abdul Aziz Al-Saud).

The Basic Law of the Kingdom of Saudi Arabia confirms the country's position as an Islamic monarchy. ${ }^{3}$ The Basic Law outlines a precise structure for the country's government. The Consultative Council, established in 1993, is charged with providing the Council of Ministers with advice regarding Saudi Arabia's policies and reviews and commentary on contracts, international accords, special rights, laws and bylaws. The Consultative Council also gives feedback on the various government ministries' yearly reports. Saudi Arabia is made up of thirteen provinces, which are further divided into governorates, districts and, finally, centres. Each province has its own provincial governor, selected by King Abdullah, and a vice governor. Provincial councils are made up of these two individuals and a minimum of ten other members. To become a member of a provincial council, an individual must first be nominated by the provincial governor, then approved by the Minister of the Interior and appointed by the King. Provincial councils submit requests for funds from the annual budget, suggest improvements and initiatives for their area and have the power to determine the particular developmental requirements of their area. ${ }^{4}$

The majority of Saudi citizens are Muslim, and Saudi Arabia is an Islamic nation and part of the Muslim world. The appeal of Muslim markets would be minimal if all of these claims were borne out in reality. ${ }^{5}$ However, Miles and Goulding note that there is increasing interest among the global academic community in researching the commercial and company law of Islamic nations, which now conduct significant amounts of trade with the Western world. It is estimated that Islamic nations conduct $87 \%$ of their trade with non-Islamic countries,

\footnotetext{
${ }^{1}$ The Kingdom of Saudi Arabia was established by the enactment of Royal Decree No 2716, dated 18 September 1932.

2 The Council of Ministers was established pursuant to Royal Order No A/13, dated 20 August 1993.

3 The Basic Law was promulgated under Royal Order No A/90, dated 1 March 1992.

${ }^{4}$ Latham and Watkins LLP, 'Doing Business in Saudi Arabia Report' (2010) 2 <www.lw.com> accessed 15 September 2011.

${ }^{5}$ L Miles and S Goulding, 'Corporate Governance in Western (Anglo-American) and Islamic

Communities: Prospects for Convergence?’ (2010) 2 JBL 137.
} 
meaning that only $13 \%$ of trade is carried out between Islamic nations themselves. ${ }^{6}$ Foreign traders and investors cannot ignore the importance of the Muslim world, especially as the international market continues to diversify.

Saudi Arabia is notable among developing Islamic nations because it enjoys good political stability, offers its private business sector liquidity and financial incentives and has a solid infrastructure, inexpensive labour and energy and low taxes. In addition, Saudi Arabia's considerable gas and petrol reserves ${ }^{7}$ make it a creditworthy and active global market. ${ }^{8}$ Oil takes a leading role in any discussion of Saudi Arabia. The country has slightly less than 245 billion barrels of oil in its reserves, thought to account for more than $66 \%$ of the oil in the Middle East and 25\% of the world's oil supply. Saudi Arabia also has as much as 1 trillion recoverable barrels of oil in its territory and thus faces no competition in oil-related industries. ${ }^{9}$ All elements of Saudi Arabian life reflect the country's oil-rich status, and this wealth forms the foundation of the liquidity in Saudi Arabia, providing high levels of confidence in investments in the Saudi Arabian market. ${ }^{10}$

El Sheikh has observed that, as investors are primarily interested in making a profit, the high liquidity enjoyed in Saudi Arabia is a strong selling point. ${ }^{11}$ Saudi Arabia's economic resources have also enabled it to create an infrastructure that meets high global standards. Investors pay very little or even no tax, and do not have to make any substantial contribution to infrastructure, such as roads, telecommunication towers or energy stations.

Considering the substantial benefits of investing in the Saudi Arabian business market, it would be reasonable to think that domestic and international investment in the country faces no real barriers. Sadly, this is not true. A key barrier to investment is the Saudi Arabian commercial and company legal system, especially its treatment of minority shareholders in private firms. The CL was implemented before commercial activity in the region began to grow. Its provisions appear to take their inspiration from civil law. Saudi Arabian company and commercial law hinder both domestic and international investment. An American or British lawyer would find it nearly impossible to provide appropriate guidance to clients operating in this jurisdiction without the support of a local legal expert. ${ }^{12}$ Investors and businesspeople have become acutely aware of the importance of legal systems and the need for clear provisions. Consequently, the Saudi legal system alone might reduce investment. ${ }^{13}$ This section describes Saudi Arabian company law and how the legal system treats both foreign and local minority shareholders.

\subsection{Basic Law of Governance}

Dispersed written rules were codified as Saudi statutory law in 1992 under King Fahd Al Saud's (1921-2005) ratification of the reform of the constitutional law. The King explicitly laid out four substantial sets of laws: the Basic Law of Governance, the Regional Law, the Council of Ministers Law and, lastly, the Consultative Council Law. $^{14}$

The Basic Law of Governance is the most vital set of laws, and contains nine chapters with 83 legal articles. The first part of the Basic Law of Governance establishes the country's framework, religion, language and capital city. ${ }^{15}$ The second part sets the succession of the Saudi throne from the parents and sons of the country's founder. ${ }^{16}$ The third part declares the fundamentals of Saudi civilisation, ${ }^{17}$ emphasising the importance of education in making each Saudi citizen a positive member of society. ${ }^{18}$

\footnotetext{
${ }^{6}$ ibid 138.

${ }^{7}$ Saudi Arabia is estimated to be the world's largest exporter and third-largest producer of oil.

${ }^{8} \mathrm{~J}$ Bancal, 'Legal, Tax and Fiscal Engineering for Industrial Co-operation in Saudi Arabia' (1993) 6 IBLJ 687.

${ }^{9}$ International Energy Agency, 'By Country, Saudi Arabia, 2008' <http://iea.org!country/n_country.asp?

COUNTRY CODE=SA\&Submit=Submit\#bottom> accessed 16 February 2011.

${ }^{10}$ F Almajid, 'A Conceptual Framework for Reforming the Corporate Governance of Saudi Publicly Held Companies: A Comparative and Analytical Study from a Legal Perspective' (PhD thesis, University of Manchester 2008) 47.

${ }^{11}$ F El Sheikh, The Legal Regime of Foreign Private Investment in Sudan and Saudi Arabia (Cambridge University Press 2003) 24. Saudi Arabia does levy varying amounts of tax on foreign companies, but they may seek exemptions under certain conditions.

12 ibid 76.

${ }^{13}$ Miles and Goulding (n 95) 137.

${ }^{14}$ Basic Law of Governance, Royal Order, No. A/90, dated 1 March 1992; Consultative Council Law, Royal Order, No A/91, dated March 1992; Regional Law, Royal Order, No A/92, dated 1 March 1992; Council of Ministers Law, Royal Order, No A/13, dated 20 August 1993.

${ }^{15}$ Basic Law of Governance (n 93) Articles 1, 2, 3 and 4.

16 ibid Article 5.

17 ibid Articles 9 and 10.

18 ibid Article 13.
} 
The Basic Law of Governance addresses economic affairs and stipulates that the government owns all natural resources. ${ }^{19}$ It identifies the country's overall financial statements ${ }^{20}$ and controlling governmental organisations (whether financial or administrative). ${ }^{21}$ Specifically, the Basic Law of Governance advises that the government should treat and counsel all citizens equally and fairly. ${ }^{22}$ Furthermore, it tasks the government with protecting human rights, civil rights and autonomy so no citizens or residents may be detained without any legal actions. ${ }^{23}$

It is claimed that Saudi Arabia has no statutory law because its legal system is based on the Quran and the Sunna. This claim is reinforced by Article 1 of the Basic Law of Governance which states that: 'The religion in Saudi Arabia is Islam and the constitution is the Book of God and the Sunna (traditions) of His Messenger'. ${ }^{24}$ Although the Basic Law of Governance is called the country's constitution, the term 'constitutional' has a different meaning in Saudi practice than in common law. From the Saudi perspective, the term indicates the fundamentals of Saudi society. Others believe that the Basic Law of Governance established constitutional law. Therefore, the Basic Law of Governance can be understood as preserving the core values of the constitution, thus acting as a true constitutional law. ${ }^{25}$ Consequently, there are conflicts between the Basic Law of Governance as constitutional law and the principal foundations of Sharia law.

\subsection{The Saudi Legal Framework}

As mentioned earlier, Sharia law is the fundamental source of law in Saudi Arabia and consists of basic principles taken from a number of texts, most notably the Quran, scholarly work on the Sharia and a collection of the sayings of the Prophet Mohammed known as the Sunna. Law in the Kingdom of Saudi Arabia is also established by legislation enacted through Royal Decrees, Royal Orders, Ministerial Circulars, Ministerial Resolutions and the Council of Ministers Resolutions. However, any enacted legislation is subject to Sharia law and must be firmly in line with the principles of Sharia.

Various different adjudicatory organisations and courts of law form Saudi Arabia's judicial system, including a number of specialised committees, the Board of Grievances and Sharia courts. Typically, the Sharia courts preside over civil claims, excluding those claims falling under the jurisdiction of another of the country's adjudicatory organisations. Sharia courts see cases concerning a range of property issues as well as family law. Most criminal prosecutions take place in a Sharia court. The country's specialised committees were created by different government agencies and ministries and have very specific jurisdictions specified in their constitutive rules. Three key specialised committees are the Committee for the Settlement of Labour Disputes, the Negotiable Instruments Offices and the Committee for the Settlement of Banking Disputes. Certain specialised committees act independently of both the Board of Grievances and Sharia courts. ${ }^{26}$

A new Law of Judiciary enacted by King Abdullah in 2007 undertook significant reform of the Kingdom's judiciary system. ${ }^{27}$ The law reorganised Saudi Arabia's judiciary bodies and dispute resolution bodies, including the creation of specialised courts, such as labour, commercial and criminal courts. The Board of Grievances now acts as an administrative court. Enacted in 2007, the Law of Judiciary is being introduced in stages and has not been fully implemented.

Whilst the principle of legal precedent that lies at the heart of the UK common law system provides a level of predictability and impartiality, the ambiguous nature of legal precedents in Islamic courts create uncertainty. In Saudi Arabia, there is no concept of a judicial precedent, which means that the decisions of a court or a judicial committee have no binding authority in other cases. ${ }^{28}$

The non-precedent nature of Saudi/Islamic law creates further potential for scepticism by Western organisations and cultures, which may feel unsure of the validity of the legal system, particularly in foreign disputes. Therefore,

\footnotetext{
19 ibid Article 14.

${ }^{20}$ ibid Article 13.

21 ibid Article 79.

${ }^{22}$ ibid Article 8.

${ }^{23}$ ibid Articles 26 and 36.

${ }^{24}$ ibid Article 1.

${ }_{25}$ Abd Rahman Al-Shlahoub, Constitutional Order in KSA between the Law and Comparative Law (Arabic edn, 1999) 91.

${ }^{26}$ Latham \& Watkins LLP (n 94) 2.

${ }^{27}$ Law of Judiciary, Royal Decree No M/78, dated 1 October 2007.

${ }^{28}$ Saudi Arbitration Regulations, Royal Decree No M/46, dated 24 April 1983; Implementing Rules, Council of Ministers Resolution, No 7/2021/M, dated 28 May 1985.
} 
foreign judgments should abide by Sharia codes and public rules. ${ }^{29}$

\section{Institutional Corporate Governance Framework}

This section first focuses on government and government-regulated institutions established to enforce compliance and see that the actions of corporations are in line with the corporate governance law.

\subsection{The Capital Market Authority}

The CMA was created in 2003 pursuant to the CML. ${ }^{30}$ It enjoys legal, administrative and financial independence, reporting directly to the King in his capacity as President of the Council of Ministries. The CMA exercises executive and legislative powers in passing and adopting regulations supporting the validity and reliability of the market's valuation mechanism. Due to its regulatory functions, the CMA is prohibited from engaging in commercial activities of any kind, to have any interest in any profit-making endeavour, to lend or borrow any funds or to acquire, own or issue any financial instruments. ${ }^{31}$ The CMA is endowed with the authority to create rules, enforce regulations and exercise mandatory power to properly discharge its duties. It may subpoena witnesses, collect evidence and compel parties to produce any books, papers, records or other documents deemed material and relevant to its investigations. ${ }^{32}$

The limitations on engaging in commercial activities extend to each employee, agent and member of the board of the $\mathrm{CMA}^{33}$ including their relatives. Article 8 of the CML states that:

Any person who becomes an employee or a member of the Board of the Capital Market Authority should, immediately upon accepting its functions, disclose to the Capital Market Authority, in the manner set forth in the regulations of the Capital Market Authority, the securities he owns or has at his disposal or the disposal of one of his relatives, and thereafter declare any change thereon, within three days of becoming aware of such change. ${ }^{34}$

Furthermore, Article 9 of the same law affirms that:

The members of the Board and the employees of the Capital Market Authority shall not engage in any other profession or job, including occupying a position or a post in any company, in the government, or within any public or private institutions. Furthermore, they shall not provide advice to companies and private institutions. ${ }^{35}$

While the individuals mentioned in the Article may hold or acquire securities and therefore have interests in commercial gains, there is a strict requirement for full disclosure of these holdings and interests, including those of their relatives, and of any changes made to these holdings and interests within three days. Full disclosure is also mandated for the agents of the CMA in matters related to the work entrusted to them by regulations. ${ }^{36}$

The CMA is a semi-governmental body governed by a board whose members are appointed. Five permanent members, who must possess high qualifications, serve for a term of five years, which may be renewed only once. After appointment, members nominate the chairman and deputy chairman and receive salaries predetermined by Royal Order. ${ }^{37}$ The CMA develops the implementing rules and regulations for the laws passed by the legislature or by Royal Decree in consultation with experts in the government agencies and the private sector. Regulations passed by the CMA include the following: ${ }^{38}$

- Anti-Money Laundering and Counter-Terrorist Financing Rules;

- Authorised Persons Regulations;

\footnotetext{
${ }^{29}$ New York Convention, Royal Decree No M/11, dated 29 December 1993.

${ }^{30}$ CML (n 5) Article 4.

${ }^{31}$ CML (n 5) Article 4(b).

32 ibid Article 5(c).

${ }^{33}$ The CMA Board was established under Article 7 of CML. Its composition, duties and responsibilities and qualification of its members are specified in Article 7 (a)-(d) of CML.

${ }^{34}$ CML (n 5) Article 8.

${ }^{35}$ ibid Article 9.

${ }^{36}$ ibid Article 8.

37 ibid Article 7(A) and (B).

${ }^{38}$ Bushra Gouda and Ali Gouda, 'The Saudi Securities Law: Regulation of the Tadawul, Stock Market, Issuers, and Securities Professionals Under the Saudi CML 2003 of 2003' (2012) XVIII Annual Survey of International and Comp Law 115 $<$ http://digitalcommons.law.ggu.edu/cgi/viewcontent.cgi?article=1160\&context=annlsurvey $>$ accessed 18 September 2012 .
} 
- Corporate Governance Regulations;

- Glossary of Defined Terms used in the Regulations and Rules of the Capital Market Authority;

- Investment Fund Regulations;

- Listing Rules;

- Market Conduct Regulations;

- Merger and Acquisition Regulations;

- Real Estate Investment Funds Regulations;

- Securities Business Regulations. ${ }^{39}$

The principal objectives of the CMA are to:

- Develop the Saudi market;

- Regulate the issuance of and trading in securities;

- Achieve transparency and fairness in securities transactions;

- Monitor the disclosure of information connected to securities and listed companies;

- Adjust the actions of the stock exchange and listed companies. ${ }^{40}$

To achieve these objectives, the CMA performs the following functions:

- Lays down policies, work plans and regulations necessary to achieve the agency's objectives;

- Formulates the implementing rules and regulations necessary to effect regulations;

- Grants the flotation of securities;

- Adjourns stock exchange actions for designated periods of time;

- Bans for cause any security traded on the stock exchange;

- Develops vital principles for external auditors who review the reports of the stock exchange, brokerage companies, investment funds and listed companies. ${ }^{41}$

It is evident that the CMA's principal role is to enact and implement regulatory measures to ensure that the SSE is properly governed and operating. The CMA Board initiates activities that until recently were performed by the Ministry of Commerce and Industry. The specific function of overseeing corporate governance provisions is delegated to the General Department of Corporate Governance.

\subsection{The General Department of Corporate Governance}

The CMA is organised so as to be able to perform its functions under the CML. It created the General Department of Corporate Governance which is charged with the improvement and implementation of the corporate governance system through the following duties: ${ }^{42}$

(1) Developing communication with specialised institutions, both local and international, which are involved in the corporate governance of publicly traded companies;

(2) Encouraging perceptions of transparency, disclosure, liability and equality;

(3) Increasing investors' knowledge of listed companies through the appropriate CGR provisions;

(4) Promoting and overseeing implementation of corporations' self-regulation of their corporate governance policies;

(5) Training representatives of listed companies in the proper implementation of corporate governance practices. ${ }^{43}$

The Corporate Governance Department has direct responsibility for monitoring and regulating companies'

${ }^{39}$ CML (n 5) Article 66.

40 ibid Article 5(A).

${ }^{41}$ CML (n 5) Article 6.

${ }^{42}$ CMA Board Annual Report (2011) 25.

${ }^{43}$ Recently, in many Saudi districts, the General Department of Corporate Governance has held workshops about preparing the report to the board of directors and completing forms related to the rules of corporate governance. See Al-Riyadh Newspaper (9 January 2012) Issue 15904. 
compliance with the CGR. The department also has the power to bring legal actions against corporations which violate the CGR through the CRSD. In the course of its oversight functions, the department analyses listed corporations' articles of associations, online and print announcements, pronouncements through the stock exchange, and annual board financial reports. The department passes its decisions about violations onto the CMA Board, which reviews the decision, the recommended penalties and the legal basis for them. ${ }^{44}$

\section{Committee for the Resolution of Securities Disputes}

Judicial authority in Saudi Arabia is conferred on three institutions: the Sharia courts, Board of Grievances and quasi-judicial committees under bodies which discharge executive and legislative functions. The quasi-judicial committees are not firmly structured because of their limited jurisdiction and oversight by governmental and semi-governmental bodies. Unlike impartial judicial bodies which take no sides, dispute committees are charged with protecting investors and market equity and resolving disputes involving the CML and its implementing regulations. ${ }^{45}$

\subsection{Securities Disputes Committee}

Two committees that perform vital roles in the implementation of corporate governance in Saudi Arabia are the CRSD and the Securities Conflict Appeal Committee. The CRSD is a quasi-judicial committee composed of several legal advisors with expertise in Islamic financial and legal transactions, capital market laws and the interpretation of financial contracts. The legal advisors are appointed by the CMA Board for terms of three years with the opportunity for reappointment after the first term. It is necessary that the advisors and their relations to the fourth degree have no direct commercial interest with the parties involved in grievances being heard. ${ }^{46}$ This qualification is intended as an assurance that the legal advisors' decisions are not biased.

The CRSD has jurisdiction to hear a broad range of disputes, including: $:^{47}$

(1) Public cases or actions brought against parties who refuse to comply with provisions of the CML and its implementing regulations;

(2) Private cases or actions brought by investors against groups in authority;

(3) Grievance cases or claims by parties against complex regulations and proceedings implemented by the CMA Board or the stock exchange;

(4) Temporary cases presented to the CRSD to obtain a ruling on transitory matters.

Despite the CRSD's broad scope of authority, it may hear cases only with the permission of the CMA, which has 90 days to consider the issue. ${ }^{48}$ Claimants may not proceed directly to the CRSD within this period. This would be seen as an intervention by the CMA in the CRSD's authority which extends beyond listed companies and exceeds that of the CMA.

\subsection{Securities Conflict Appeal Committee}

The Securities Conflict Appeal Committee comprises three members nominated by the Council of Ministers' Royal Decree. They serve for a term of three years subject to renewal. In most cases, the appointed members are representatives from the Ministries of Finance and Commerce and Industry and from the Bureau of Experts under the Council of Ministers. ${ }^{49}$ Decisions by the CRSD can be appealed to this Committee within thirty days of the decision. The Appeals Committee may decide to accept or refuse an appeal, and its decision is final and binding. ${ }^{50}$

\section{The Saudi Stock Exchange}

The SSE was established in 1984 in response to the launch of other stock exchanges in neighbouring countries, particularly Kuwait and Jordan. In addition, the public exhibited growing awareness and interest in stocks and stock trading, and Saudi corporations planned to switch from national to public ownership. The SSE was created under the supervision of the Ministry of Commerce and Industry and SAMA ${ }^{51}$ and initially had 70 listed

\footnotetext{
${ }^{44}$ CML (n 5) Article 7(d), empowering the CMA to delegate its functions through published Resolutions.

45 ibid Article (A) and (B).

${ }^{46}$ CML (n 5) Article 25(A).

47 ibid Article 25(D).

48 ibid Article 25(E).

${ }^{49}$ CML (n 5) Article 25(G).

${ }^{50}$ Resolution of Securities Disputes Proceedings Regulations 2011, Article 39.

51 Asam Al Ghamdi, Commercial Law: Business, Dealer, Commercial Companies (Arabic edn, Shaqri Library 2007) 38.
} 
companies. By 1996, with a capitalisation of $\$ 45.9$ billion and a market price-to-earnings ratio of 13.1 times, the SSE ranked as the thirteenth largest developed market in the world and the dominant stock market among Arab Gulf countries. $^{52}$

In 2003, the new SSE was reformed under the CML for the purpose of trading in securities. ${ }^{53}$ The SSE is governed by a board of governors representing a number of governmental agencies, including the Ministry of Finance, Ministry of Commerce and Industry and SAMA. Other members include representatives from four licensed brokerage companies and two listed corporations. ${ }^{54}$ Over time, the number of listed companies has more than doubled from the original 70 to 150 .

Among the SSE's most important responsibilities in relation to the corporate governance framework is the oversight and enforcement of the requirement for corporations to hold annual GSMs and to ascertain that shareholders are accorded their rights through these meetings as guaranteed by law. The SSE also discharges obligations to: ${ }^{55}$

(1) Guarantee the equity of listing requirements;

(2) Ensure that transactions are impartial and fair;

(3) Ensure that firms meet transparency requirements;

(4) Certify technical mechanisms and information for securities listed on the stock exchange;

(5) Resolve disputes between board and shareholders and approve regulations.

The SSE represents a form of self-regulation because of the broad participation by representatives of brokerage companies and listed companies. Regulation is not only a one-way, top-down approach but follows a more responsive and more effective approach.

\section{The Ministry of Commerce and Industry}

The major government agency which oversees regulatory measures and corporate governance is the Ministry of Commerce and Industry. It is charged with certifying that the listing of companies is performed with full compliance with the CL, good corporate governance principles and respect for shareholders' rights. ${ }^{56} \mathrm{~A}$ vital department under the Ministry of Commerce and Industry is the Department of General Companies. It is responsible for assessing and modifying the articles of association of newly-established corporations. ${ }^{57}$

\section{The Accounting and Auditing Professions and the Saudi Organization for Certified Public Accountants}

Standing vanguard over the entire corporate governance framework is the auditing profession, which acts with professional detachment and strict standards. Audits assess the financial condition and conduct of the company, particularly managerial actions. Auditors are subject to a wide range of liabilities in the conduct of their functions, which ensures the competent and impartial assessment of firms' governance. Recent events in the international collapse, however, have cast a negative light on this profession. Its members have been perceived as remiss in the discharge of their functions and a causal factor in the global financial crisis. ${ }^{58}$ The Saudi accounting and auditing profession is believed to have issued unprofessional and misrepresenting assessments, which were a principal cause of the Saudi stock market collapse in 2006.

The first accounting and auditing firm in Saudi Arabia was established by the Ministry of Finance in 1957. The Ministry issued permits to seven duly licensed accounting and auditing companies, one Saudi and the rest foreign. ${ }^{59}$ There was no earlier licensed Saudi accounting or auditing firms because of the lack of suitably educated and trained accountants and auditors. ${ }^{60}$ The CL specifies the qualifications for certification in accounting and auditing firms, including nationality, residence, professional standing, members' certificates and

\footnotetext{
${ }^{52}$ International Finance Corporation, Emerging Stock Markets Fact Book 328 (World Bank 1995).

${ }^{53}$ CML (n 5) Article 20(A).

54 ibid Article 21.

${ }^{55}$ ibid Article 20(C).

${ }^{56}$ CL (n 7) Article 49.

${ }^{57}$ ibid Article 83.

${ }^{58}$ Istemi Demirag and Jill Solomon, 'Guest Editorial: Developments in International Corporate Governance and the Impact of Recent Events' (2003) 11(1) Corporate Governance: An International Review 1.

${ }^{59}$ Awad Al Rahele, 'Audit Committees as One of the Pillars of Corporate Governance' (2008) 22 Journal of King Abd al-Aziz University of Economics and Management 179.

${ }^{60}$ Hussam Al Angari, Auditing in the Kingdom of Saudi Arabia (Arabic edn, Sarawat Library 2004) 10.
} 
experience. The CL has become a significant driver of the continued professionalisation of the accounting and auditing field.

The CL orders corporations to submit their financial reports to a chartered public accounting and auditing company. The chartered company is also empowered to access the company's records, demand information about its operations, assets and liabilities, and perform the necessary due-diligence asset inspection to determine the accuracy of valuations. ${ }^{61}$ However, the accounting profession is still hampered by the lack of an appropriate set of accounting standards applied uniformly to companies with comparable operations. The CL also lacks the body of appropriate legislation to properly regulate the accounting and auditing profession. ${ }^{62}$

For these reasons, the SOCPA was founded in 1992 with the task of overseeing the accounting and auditing profession and promoting its development and the formulation of accounting standards and principles. SOCPA's stated functions are to: ${ }^{63}$

- Review, develop and approve accounting standards;

- Review, develop and approve auditing standards;

- Establish the necessary rules for fellowship certificate examination (CPA exam), including for the professional, practical and scientific aspects of the auditing profession;

- Organise continuous education programmes;

- Establish an appropriate quality review programme to ensure that certified public accountants implement professional standards and comply with relevant provisions and by-laws;

- Conduct special research and studies in accounting, auditing and related subjects;

- Publish periodicals, books and bulletins on accountancy- and audit-related subjects;

- Participate in local and international committees and symposiums relating to the profession of accounting and auditing.

To help professionalise accounting and auditing as instruments of corporate governance, the SOCPA has issued recommendations to the boards of directors of various listed Saudi corporations about the inadequacy of transparency in their audit committee functions and the lack of satisfactory control rules. It is largely due to the perseverance of the SOCPA that these corporations have committees discharging the board's nomination, remuneration, risk and audit oversight functions. The first of these specialised committees were established only two years ago. ${ }^{64}$

\subsection{Accountability from an Islamic Perspective}

The concept of accountability is one of the most important aspects of Islam because of its link to belief in the Day of Judgment. This belief is one of the six articles of faith for Muslims, for whom, not the present life, but life after death is not the ultimate goal. The Quran calls the Day of Judgment by many names, including the Day of Accountability, the Day of Resurrection, the Hour and the Last Day, when all will be called to give an accounting of our decisions, including those made in business and work. For Muslims, therefore, accountability is not only an ethical concept but more a moral and spiritual one, for which all good Muslims are eternally answerable to God. ${ }^{65}$ As all people will be questioned about their actions, Sharia law stipulates that all deeds be free of cheating and stealing. This belief supports the concept of disclosure and transparency in corporate governance as all the company proceedings and operations will be shown honestly to the public.

\section{Saudi Corporate Governance Regulations (2006)}

The CMA first introduced the CGR as a set of voluntary, not mandatory, guidelines, unlike other regulatory functions (e.g. market conduct and merger and acquisition regulations) which were compulsory from the start. The CMA declared that the role of the CGR was to provide standards for the administration of listed corporations and encourage compliance. At its discretion, the CMA may enforce the CGR articles provided that

\footnotetext{
${ }^{61}$ CL (n 7) Article 130.

${ }^{62} \mathrm{~S}$ Mohammad Al-Amari, 'The Development of Accounting Standards and Practices in the Kingdom of Saudi Arabia' (PhD thesis, University of Glasgow 1999) 71.

${ }^{63}$ Saudi Certified Public Accountants (2007) 10.

${ }^{64}$ SOCPA (n 153) 10.

${ }^{65}$ Reem, 'The Importance of Accountability' (Inside Islam, 2012)<http://insideislam.wisc.edu/2012/03/the-importance-of-accountability/> accessed 27 August 2013.
} 
the CMA Board determines the measure is appropriate for the Saudi market. ${ }^{66}$

Shareholders and other stakeholders play a vital role in corporate governance by providing a counterbalance to the board and management who tend to act in their own interests which might conflict with stakeholders. The interests of the stakeholders are the motivation for the practice of good corporate governance. Stakeholders (employees, shareholders, community, society) are most affected by corporation actions decided by the board and management but are the least directly involved in the making of these decisions.

The World Bank (WB) ranked Saudi Arabia $17^{\text {th }}$ out of 183 countries evaluated for the protection of investors, particularly minority shareholders. ${ }^{67}$ This indicates that Saudi law is well within the norms of most countries. The rights accorded shareholders are specified in Article 3 of the CGR: ${ }^{68}$

(1) The right to a share of the profits of the firm through dividends;

(2) The right to a proportionate share of the corporation's assets when liquidated;

(3) The right to dispose of their shares in the firm according to their preference;

(4) The right to attend the general shareholders' meetings, to contribute to the discussion, to ask management to explain their decisions and to vote on applicable resolutions;

(5) The right to oversee the activities of the board of directors;

(6) The right to file responsibility claims in a liability action against board members;

(7) The right to request and access information without prejudice to the corporation's benefits and in a way that does not reverse the CML and the implementing regulations; and

(8) The right to appoint and remove members of the board of directors.

Regarding the rights of shareholders in Saudi Arabia, the 2009 WB Report on the Observance of Standards and Codes (ROSC) states that Saudi Arabia has either fully or broadly implemented all the sub-principles within Principle IIA on shareholder rights protection. Regarding shareholders' rights to participation and information about fundamental corporate changes, the ROSC finds that Saudi Arabia has 'broadly implemented' all the sub-principles within Principle IIB. The exception is Sub-principle IIB 3 on extraordinary transactions. It has not been implemented, indicating major shortcomings in this area. According to the assessment, the available legal provisions 'appear too broad to capture the essence of the principle'. ${ }^{69}$

The Returns of Spontaneous Circulation in the ROSC highlight a number of shortcomings regarding this principle. Several obstacles impede some entitled shareholders, mostly those holding less than a specific number of shares, from attending general shareholder meetings (GSMs). There are no requirements for companies to disclose their remuneration policies. Shareholders may not vote by post or electronically although they may, in writing, delegate another shareholder to vote on their behalf. While companies may issue different classes of shares and are required to disclose descriptions of groups granted disproportionate control, the disproportionate control resulting from shareholder agreements are not disclosed. ${ }^{70}$

In Saudi Arabia, the CMA's Mergers and Acquisitions Regulation ${ }^{71}$ regulates corporate takeovers, with the Competition Law containing certain restrictions against mergers. In addition, companies must treat all shareholders equally during a takeover. The assessment observes that, unless stated by internal company policy, there appears to be no obligations for institutional investors to vote or consider voting. ${ }^{72}$ Therefore, the Saudi corporate governance laws that relate to shareholders are less well established and arguably do not demand the same level of confidence as their counterparts in non-Islamic-based law systems.

Principle IIIA on minority protection states that all holders of the same class of shares should be treated equally. For these sub-principles, Saudi Arabia received ratings ranging from fully and broadly implemented to partially implemented in the 2009 WB ROSC. The assessment also found Principle IIIB on the prohibition of insider trading and abusive self-dealing to be partially implemented and Principle IIIC on the disclosure of material

${ }^{66}$ CML (n 5) Articles 20(a) and 21.

67 See U.S.-Saudi Arabian Business Council, 'Saudi Arabia ranks $12^{\text {th }}$ most business friendly Economy in the World $<$ http://www.us-sabc.org/custom/news/details.cfm?id=1156\#.VBKdZG9O5dg > accessed 24 September 2013.

${ }^{68}$ CGR (n 8) Article 3.

${ }^{69} \mathrm{WB}$ (n 85) 18-20.

70 ibid 19-22.

${ }^{71}$ Mergers and Acquisitions Regulation, CMA Board's Resolution No 1-50-2007, dated 3 October 2007.

${ }^{72}$ WB (n 85) 23. 
interests of board members and key executives to be broadly implemented. This evaluation details several ex-ante and ex-post protection measures available to minority shareholders. Under certain circumstances, however, these shareholders do not have the means to require the company to purchase their shares. ${ }^{73}$

In addition, voting by proxy is still limited in Saudi Arabia although the evaluation does note that the Ministry of Commerce and Industry ${ }^{74}$ is considering the option of issuing rules on making use of phone and internet for contribution purposes. The CML and Market Conduct Regulations define and prohibit insider trading and manipulative practices.

Al-Fawaz claims that the voting system in Saudi Arabia is not compatible with corporate governance and economic health, which contribute to the development and the flow of capital markets. ${ }^{75}$ The voting system allows for the largest shareholder or allied shareholders to use their votes to tighten the control of other shareholders by nominating themselves. Majority or large shareholders can take advantage of such companies as many individual shareholders (small shareholders or speculators) do not attend GSMs, and these require a quorum only of those in attendance. It follows that a large part of the ownership is representative of the board of directors which sometimes possesses up to $10 \%$ of company stock. The practical result of this voting system is that not all shareholders have equal rights, duties and interests. This arguably is a manifestation of individual control at the expense of the institution.

Al-Fawaz argues that the solution is to expedite the issuance of new corporate law even though national economic interests might make it advisable to delay reform of the voting system (one vote per share) ${ }^{76}$ Companies have proposed system guarantees of minority rights through reform of this flaw in voting so it is advisable to expedite the approval of this reform. ${ }^{77}$

Further to that, legislation displays a lack of enthusiasm for corporate governance. Advocates hope to apply the CMA's obligations in full and give the SAMA another role in the governance of the banking sector. Several parties have resisted these regulations in an attempt to maintain a comfortable, profitable monopoly. Amid talk of economic and financial reforms, and price increases in the Kingdom, perhaps the first step to resolve these conflicts is to break this monopoly and force entrepreneurs to innovate, take risks and not exploit the system to maximise their narrow interests at the expense of those of the nation, citizens, transparency and radical economic reforms. The government, too, should be cautious as it has influential shares in some joint stock companies (JSCs). Developing mechanisms for electronic voting is also recommended.

However, investors have no cause to engage in insider trading. In addition, the law requires that company boards describe all interests and rights of their members, key executives and immediate family who have shares in the company or its subsidiaries. Violations of such rules by board members or managers are subject to fines. ${ }^{78}$ In Saudi Arabian corporate governance, stakeholders are also of great importance, as reflected in the laws which protect them.

The case of Saudi Integrated Telecom Company (SITC) shows that official departments are willing to interfere to resolve an issue. This is not the first incident which has affected the rights of minority shareholders. Multiple companies had done so earlier but what happened to the SITC had not happened to any other company. The company offered public subscriptions without paying the full share of the founders and used bank guarantees instead of bank certificates of deposit from the shares owned by shareholders. Many parties contributed to the accumulation of the problems. First, the bank abrogated its responsibility in pledging to cover the Initial Public Offering (IPO), an action known to run contrary to statutory procedures for IPOs. As the source of collateral, the bank should bear responsibility for the silence about the preliminary prospectus which shows the use of financial guarantees as certificates of deposit for shares possessed by the company's principal owners. For its silence, the newsletter also shares responsibility for the consequences.

This process also involved two institutions reputed to be cautious and conservative: the SAMA and Ministry of Commerce, which did not prevent explicit violations. The CMA also has some responsibility to bear for tolerating offering the company shares without applying the LR which the prospectus refers to. In addition, the

\footnotetext{
${ }^{73}$ ibid. See also Lena Al-Zahrawi, 'The Impact of Corporate Governance on the Evaluation of the Performance of Investment Funds Applied to the Case of the Saudi Financial Market' (PhD thesis, Syria Higher Institute of Business Administration 2009) 54, 60.

${ }^{74}$ Establishing the Ministry of Commerce and Industry, Royal Order No 5703/5/22/10, dated 17 March 1954.

${ }^{75}$ F Al-Fawaz, 'Loss of Minority Rights: Between Major Shareholders and Corporate Governance' (Al-Eqtisadi Newspaper, 2007).

${ }^{76}$ Al-Fawaz (n 165).

77 ibid.

${ }^{78}$ ibid.
} 
silence of the Telecommunications Authority and the monetisation of non-adherence to the safeguards to stop trading shares raise questions about this body's role in misleading shareholders and other official bodies during the establishment of the company without supportive market conditions.

The CMA suspended the shares of SITC on the SSE on 4 January 2012. Order 05/09/1433 AH adjusted the company's status. The CMA stated that it would consider further action if the company had not repositioned itself six months after the date of this decision.

This issue was clear cut. The company founders had not abided by corporate law or listing rules and procedures and, intentionally or unintentionally, exposed shareholders to high-risk practices. Thirty-five per cent of the company's shares were owned by shareholders who did not know the direction of the company and were unfamiliar with the CMA, Ministry of Commerce, SAMA and Board of Grievances. ${ }^{79}$

These practices prove beyond doubt that the status of shareholders, especially minority ones in Saudi Arabia, is still in the early stages compared to developed markets. There is no absolute answer to who is responsible for the lack of protection of minority shareholders. No unions or clear legal procedures to recover their rights or receive compensation for losses suffered as a result of errors by company leaders and other regulators exist. In developed countries, such incidents prompt the enactment of laws to address problems that have occurred, but many countries remain silent about such situations.

Although the CMA's 2004 Market Conduct Regulations include laws to prevent market manipulation, protection of minority shareholders is not guaranteed in the execution of laws and regulations. Small shareholders might be afraid of taking the initiatives as they do not know the risks. Therefore, the CMA, as the regulator of the financial market, should invite small shareholders to create blocs protected by a specially formed CMA special unit. This unit should be made of expert jurists familiar with the financial markets who can inform shareholders or groups of shareholders of their rights and advise them during any legal claims. ${ }^{80}$

For example, the CMA stopped the trading of stocks in Bisha in January 2007 because its losses reached a large percentage of its capital. The CMA asked the company to reissue its financial statements for the third quarter. Where was the board of directors when the company suffered losses in successive years? Over the past three years, as sales decreased, the company sought liquid investments in investment funds. The board of directors certainly sought any priority or initiative to improve the status of the company's primary activities. However, the company did not have a legal official at the time of the auction for the sale of outstanding shares. This created new problems with the auditor and with calculating the return on the auction revenue, and required doubling the integrity of financial systems and control. ${ }^{81}$

It has been proven that limiting the Governing Council which handles shareholders' money allows shareholders to claim the legal rights to determine corporate governance, control the work of the board and hold members of the council responsible.

According to the 2009 WB ROSC, Principle IVA on the adherence to the rights of stakeholders is broadly implemented in Saudi Arabia. Both Principle IVB on the effectiveness of redress for violations of stakeholder rights and Principle IVC on the development of performance-enhancing mechanisms for employee participation were found to be partially implemented. ${ }^{82}$ Principle IVD on stakeholder participation in the corporate governance process was not applicable in the Saudi Arabian context. The 2009 assessment deemed Principle IVE on the protection of stakeholder rights in the reporting of illegal or unethical behaviour not to have been implemented. Saudi Arabian law contains 'no specific whistle-blower mechanisms' ${ }^{83}$ Principle IVF on the existence of a complementary insolvency framework was assessed as broadly implemented. ${ }^{84}$

In addition, the $\mathrm{CL}$ does not have provisions that give stakeholders the right to provide input on matters related to company governance. The CGR, however, require that companies establish written policies organising boards' relationships with stakeholders. ${ }^{85}$ While the CGR requires dispute settlement mechanisms between companies and their stakeholders, such mechanisms are not detailed or distinguished for different types of stakeholders.

\footnotetext{
${ }^{79}$ A Al-Husseini, 'Integrated Telecom Co: Minority Missed' (Al-Eqtisadi newspaper, 2012).

${ }^{80}$ Al-Eqtisadi, 'Chief Executive of KSB Capital Group: Protection of Minority Shareholders' (2007).

${ }^{81}$ ibid.

${ }^{82} \mathrm{WB}(\mathrm{n} 85) 26$.

${ }^{83}$ WB (n 85) 27.

84 ibid 27.

${ }^{85}$ I Almataz, 'A Careful Reading of the List of Corporate Governance in the Kingdom' (Aleqt newpaper, 2007) issue 5011<www.aleqt.com> accessed 19 October 2011.
} 
Despite the CGR requirement for written CSR policies, the assessment found that few Saudi companies included these in their annual reports. According to the 2009 ROSC, recent amendments to the Offers of Securities Regulations introduced employee share options and incentive schemes but, at the time of the report, these had not been ratified. ${ }^{86}$

Regarding the legal principles of disclosure and transparency in Saudi corporate governance, Principle VA outlines the standards for the disclosure of different types of corporation material information. Its sub-principles were all rated as either broadly or partially implemented, with the exception of Principle VA7. This sub-principle on the disclosure of stakeholder issues was found not to have been implemented as the CGR disclosure requirements regulating company-stakeholder relationships were still 'too new to be tested' ${ }^{87}$

The 2009 WB ROSC also found that Saudi Arabia had partially implemented Principle VB on the standards of financial and non-financial disclosures, Principle VC on auditing and auditor requirements, Principle VD on auditor accountability and Principle VE on the accessibility of disclosed information. Principle VF on the disclosure of conflicts of interest by analysts, brokers and rating agencies was assessed as not implemented. ${ }^{88}$ Although the Authorised Persons Regulations appear to capture most core principles of the International Organization of Securities Commissions (IOSCO) Statement of Principles for Addressing Sell-side Securities Analyst Conflicts of Interest, the legal framework as a whole does not necessarily address these regulations. ${ }^{89}$

Public disclosure and periodic reporting requirements of listed companies are detailed in the CL, CML and CMA LR. However, the evaluation observes that disclosures related to beneficial ownership 'appear to be still limited in relation to intra-group relations and significant cross-shareholdings'. ${ }^{90}$ The LR require prompt ex-ante disclosure of transactions between the company and related parties but no disclosure before such a transaction is carried out. Listed companies in Saudi Arabia must comply with local financial reporting standards issued by the SOCPA. The 2009 action plan issued by SOCPA for the International Federation of Accountants (IFAC) states that SOCPA has set as an objective the convergence of national standards with International Financial Reporting Standards. ${ }^{91}$ It has been noted that the board of a corporate organisation, as well as its shareholders, is of crucial importance to the notion of corporate governance. What, therefore, of the legislations that dictate the actions and responsibilities of a board in a corporate organisation in Saudi Arabia?

According to the evaluation, fiduciary duties are still emerging legal concepts in Saudi Arabia, and compliance with the CGR on the board's key functions is still in the early stages as is the effective enforcement of penalties for violations of fiduciary duties. ${ }^{92}$ Shareholders possess the right to file liability lawsuits against directors through the redress mechanisms described in the CL. However, no laws or regulations pertain specifically to minority shareholders. ${ }^{93}$ To date, no lawsuits involving directors' liabilities have been filed in Saudi Arabia. The evaluation finds that the $C L$ requires disclosure of remuneration methods and thresholds but there are no specific laws or regulations on aligning the compensation of the board of directors and senior executives with long-term company and shareholder interests. ${ }^{94}$ Similarly, the evaluation also noted a lack of provisions in the CL and CGR concerning the disclosure of board nomination procedures. The WB evaluation also observed that not all companies possessed an internal audit function. The IFC and Hawk Amah Institute for Corporate Governance's regional survey, as cited by the 2009 WB ROSC, found fairly low cross-board memberships across Saudi Arabia.

This discussion has given an overview of company law and its operation in Saudi Arabia. A related theme will now be considered: the accountability framework within the context of Saudi corporate governance. ${ }^{95}$

The legal protection of minority shareholders does not mean that they and their interests cannot be relegated to a position inferior to that of other shareholders. Minority shareholders rights are defined, enforced and protected by law. However, as seen in Abu Aynain's 2013 article in Al-Riyadh, these reforms are inadequate to protect

\footnotetext{
${ }^{86}$ WB (n 85).

${ }^{87}$ ibid 27-29. See also Aidhamed Al-Shammari, 'Corporate Governance in Saudi Arabia Reality and Ambition' (First Scientific Conference of the Faculty of Economics University of Damascus) 11, 12.

${ }^{88} \mathrm{WB}(\mathrm{n} 85)$ 30-31.

${ }^{89}$ WB (n 85) 31.

${ }^{90}$ ibid 28.

${ }^{91}$ WB (n 85) 29.

92 ibid 31. See also Al-Zahrawi (n 163) 45, 48.

${ }^{93}$ ibid 32.

94 ibid 32. See also Al-Shammari (n 177) 27.

${ }_{95}$ Ahmed Ragab Abdel Malik Abdurrahman, 'Measuring the Extent of Transparency and Disclosure in Published Financial Reports of Companies Traded in the Saudi Capital Market Study Applied the Theory of' (King Faisal University) 8, 19.
} 
shareholders' rights and guarantee transparency of operations. Aynain discusses a crisis involving integrated telecommunications company Almutakmilah which had a difference between the book value of its shares at SR900 million and the value at market price of SR2,430 million. This could be a distorted picture as the market increased the price of the stock shares of a firm accused of offences. ${ }^{96}$

The second-generation family managers of Saudi firms are not well prepared to appoint independent boards of directors and professional chief executive officers (CEO) to manage the company according to the board's decisions. Consequently, firms' financial disclosure is not sufficient, and shareholders companies do not have enough accurate information about the companies in which they have invested. Therefore, the Saudi government is encouraging firms to adhere to corporate governance practices without resorting to mandatory regulation.

Regarding the jurisdiction process, Al-Nasiry describes the SITC case in which the company lawyer revealed that the responsible bodies did not agree to bring issues to the judiciary. ${ }^{97}$ However, the company management felt that the process was contrary to the company's interest and violated regulations. Although there was a liquidation process, its liquidation was settled by bureaucracy instead of a court of law. This situation indicates the lack of legal resort for parties involved in liquidation.

This regulatory shortcoming might result in shareholder losses during liquidation. The liquidation decision on SITC gave non-founder shareholders $9 \%$ less than the book value of their shares and nearly $60 \%$ less than market value. Bypassing the judiciary harms the voiceless shareholders who must appeal the decision in a court of law - a lengthy process because unclear regulations on liquidation might delay or deny justice. ${ }^{98}$

Although regulation of the liquidation process is lacking and the law modifies the term of limited companies, it is crucial to understand that Article 180 of the CL is the only statutory limitation of the doctrine concerning the separation of legal personality in Saudi Arabia. This article states that, if a limited liability company's losses exceed $50 \%$ of its share of capital, its shareholders lose their limited liability and become responsible for the company's debts. ${ }^{99}$ At this point, dividends may not be distributed to shareholders except for net profits. If shareholders receive a distribution that is not from the net profits, they can claim from shareholders the amount that exceeds the net profit. During the dissolution of a company, creditors need to be paid from profits before shareholders are. What remains is then distributed among shareholders. ${ }^{100}$

In addition, thirty days after the $50 \%$ limit has been exceeded, a meeting must be called to consider whether the company should continue to exist or be dissolved before the expiration of the period indicated in the company's articles of associations. ${ }^{101}$

Article 176 limits the company's ability to distribute profits to shareholders. This Article stipulates that a company must set up reserves and accumulate a reserve fund of up to $50 \%$ of share capital. Each financial year, companies must transfer at least $10 \%$ of their annual profits into reserves until they equal or exceed $50 \%$ of the company's share capital. ${ }^{102}$

\section{Evaluation and Analysis of the Saudi Corporate Governance Framework}

The Saudi Corporate Governance Framework is benchmarked against the OECD Principles of Corporate Governance, and is subject to the ROSC, a programme under the joint auspices of the WB and the International Monetary Fund (IMF). This analysis focuses on listed companies but does make country-wide observations on the general regulatory and legal framework for governance and accountability. The 2009 ROSC country assessment for Saudi Arabia noted an emerging awareness of the importance of good corporate governance as a result of the deep slump and volatile market of 2006 that was caused by a lack of disclosure and transparency among listed companies.

Since then, several initiatives to promote legal and institutional reform in the Saudi corporate governance system have been undertaken, which observers feel will ensure that companies use their resources more efficiently and will engender better relations with workers, creditors and other stakeholders. The Saudi framework includes the

\footnotetext{
${ }^{96}$ F Abu Aynain, 'The Market Value of the Shares of the Integrated 2430 Million and Shareholders' Equity Fell to 900 Million' (Al-Riyadh Newspaper, 9 May 2013).

${ }^{97}$ I Al-Nasiry, 'Responsible Bodies Reject the Judiciary and the Withdrawal of the License of Historical Precedent' (Al-Eqtisadi Newspaper, 2013) Issue 7150.

${ }^{98}$ AH Omari, 'Integrated: Who Will Pay for the Mess?' (Al-Eqtisadi Newspaper, 2013) Issue 7154.

${ }^{99}$ CL (n 7) Article 180.

${ }^{100}$ ibid Article 180.

101 ibid.

102 ibid Article 176.
} 
2006 CGR for listed companies, guidelines on corporate governance best practices for banks and strengthened supervisory functions in the financial sector.

The CMA is responsible for regulating and managing the Saudi Arabian capital markets and other areas related to corporate governance, as defined and established in the first chapter. The CMA has a level of legal, financial and bureaucratic autonomy and answers only to the prime minister. ${ }^{103}$ The CMA's responsibilities include the following:

(1) Setting financial rules and regulations;

(2) Ensuring that these rules are followed;

(3) Acting as an independent committee for the resolution of disputes;

(4) Ensuring the growth of capital markets and the corporate elements of the Saudi Arabian economy (including the governance of the SSE);

(5) Ensuring, through its Corporate Finance and Issuance Divisions, that any potential and actual investors are given all the information they may require to take objective decisions about their investments, and that all parties adhere to the rules and regulations, as above; and

(6) Contributing to policy ideas and implementations conducive to the growth of the Saudi economic markets and infrastructure.

To show the CMA's seriousness in enforcement, it filed a case against Al-Ahmary for violating Article 49 of the CML and Articles 2 and 3 of the Market Conduct Regulations ${ }^{104}$ when trading shares of various companies in 2008. The CMA charged him with committing fraud, manipulation and creating misleading impressions. He was banned from offering securities through his website, which was closed down. He was ordered to pay the revenue due to the CMA as well as a penalty. ${ }^{105}$

Other duties of the CMA are to: ${ }^{106}$

(1) Develop the capital market and promote suitable standards for all entities in securities trade operations;

(2) Maintain fairness and transparency in securities transactions;

(3) Develop appropriate measures to reduce risks related to security transactions;

(4) Protect investors and the public from unfair practices, such as fraud, manipulation and cheating, in trading information; and

(5) Regulate and monitor full disclosure of information related to securities and issuers.

The CMA is chiefly responsible, within the Saudi power structure and hierarchy, for implementing the rules, instructions and procedures that amount to the implementation of the corporate governance regulations in accordance with the cultural (Islamic) laws of the land. ${ }^{107}$ The following rules are imperative for the successful fulfilment of these objectives and are directly implemented and investigated by the CMA board:

- Anti-money laundering and counter-terrorist financing rules;

- Merger and acquisition regulations;

- Investment fund regulations;

- Corporate governance regulations;

- Real estate investment fund regulations;

- Securities business regulations;

- Authorised persons regulations;

- Market conduct regulations;

\footnotetext{
${ }^{103}$ CML (n 5). See CMA, 'About CMA'<http://www.cma.org.sa/En/AboutCMA/Pages/default.aspx?> accessed 5 June 2011.

104 Market Conduct Regulations, Capital Market Authority Board's Resolution, No 1-11-2004, dated 4 October 2004.

${ }^{105}$ Decision No 313/L/D1/. CMA, 'Announcement by the CMA Concerning Issue of Final Decision by the CRSD Condemning a Violator to the CMA Law and Regulations' (2008).

${ }^{106}$ CMA (n 193).

107 ibid.
} 
- Offers of securities regulations;

- Listing rules; and

- A glossary of defined terms used in the regulations and rules of the capital market authority.

It should be added that, from an objective perspective, the principles and guidance of corporate governance in Saudi Arabia are rather commendable. In February 2009, the WB released the ROSC on Corporate Governance in Saudi Arabia, which noted that laws, regulations and institutions in place 'generally reflect international good practice'. ${ }^{108}$ However, 'in the wake of the market correction of 2006, market regulators recognised the need for better corporate governance via legal and institutional reforms and passed the CGR for listed companies strengthening the supervisory functions across the financial sector'. ${ }^{109}$ The implementation of corporate governance by companies in Saudi Arabia is still in the early stages. ${ }^{10}$

Unsurprisingly, there are a number of proposed recommendations which, if followed, will enable Saudi Arabia to bring its actual and proposed corporate governance closer to what is expected by international standards. ${ }^{111}$ These recommendations include changes to the structure of the CGR and better implementation of the principles of the law in legal practice. The WB report notes that:

The CMA is in the process of implementing a three-phase approach to improving corporate governance practices in Saudi Arabia. Phase one was completed with the publishing of the CGR and phase two, which is currently in progress, aims to educate market participants on its application. The third phase will comprise revisions to the CGR, with a possibility of making compliance with some or all of the regulation mandatory. ${ }^{112}$

That the World Bank, in its ROSC, could conclude impartially that the Saudi corporate governance laws, regulations and institutions 'generally reflect international good practice' is significant, particularly given the allegations of economic corruption aimed at Saudi Arabia, as discussed previously. This conclusion should encourage non-Arabic corporate organisations to carry on business in Saudi Arabia and with Saudi companies. ${ }^{113}$

It has been established that the CMA has the power to investigate and enforce rules and regulations within the context of corporate governance. ${ }^{114}$ On this subject, however, one might add that, according to the 2009 World Bank ROSC, the CMA has also improved its consultative process and started more actively interacting with relevant stakeholders in developing new regulations. The 2009 ROSC found a clear division of responsibility between the CMA and the SAMA and, in general, observed a 'significant degree of cooperation between the various financial sector regulatory bodies'. ${ }^{115}$ Both the CMA and SAMA seem to possess adequate supervisory resources and are economically independent. They work to build awareness of the importance of sound corporate governance practices amongst companies, shareholders and stakeholders. ${ }^{116}$

As the legal context in Saudi Arabia is based upon Sharia law and the law is derived from Sharia principles and notions of justice, it is necessary to return to this legal framework to provide a full picture. In the early 1980s, SAMA, the central bank of Saudi Arabia, issued a document addressing the responsibilities of the board of directors of Saudi commercial banks, including the implementation of a system of accounting and internal controls. ${ }^{117}$ A further guidance document issued in 1996 concerned the role of the board's audit committee.

In 2004, the SAMA published a circular that affected bank directors and senior managers. Until 2003, the SAMA had been in charge of regulating and monitoring market activities in Saudi Arabia. The CMA was established in July 2003 under the CML, leaving SAMA with the role of regulating banks and insurance companies. As noted earlier, the CMA issued the CGR following the 2006 market correction, when market regulators focused on legislative and institutional reforms to improve corporate governance in Saudi Arabia. The 2009 World Bank

\footnotetext{
108 WB (n 85) 3.

109 ibid 3.

110 ibid 3.

111 ibid 3.

112 WB (n 85) 3.

113 ibid 6.

114 ibid 6.

115 ibid 6

116 ibid 3

${ }^{117} \mathrm{H}$ al-Sayari, 'Corporate Governance for Banks in the Kingdom of Saudi Arabia' (High-Level Roundtable Discussion for Bank Executives on Corporate Governance for Banks in Saudi Arabia, Institute of Banking, Riyadh, 22-23 May 2007).
} 
ROSC found general adherence to be low in the first year of the adoption of the CGR, applicable to listed companies on a 'comply-or-explain' basis. The SAMA is also 'drafting a corporate governance manual for banks'. 118

This history proves how Islamic law is being affected and is evolving within the business and economic setting of Saudi Arabia. If the Saudi economy is to grow as desired, a shift from Sharia law towards more international (i.e. European and American) business laws and rules is necessary. However, this evolution must not come at the expense or alienation of the Arabic world which is itself so intertwined with the Saudi economy at a cultural and a financial level.

According to the 2009 World Bank ROSC, companies in Saudi Arabia adhere to a one-tier board system. The Tadawul serves as Saudi Arabia's Stock Exchange, which is the largest in the Arab world, with a market capitalisation of US\$519 billion at the end of 2007. According to the World Federation of Exchanges, the Tadawul had 122 listed companies as of June 2008. Despite some market liberalisation in 2006, foreign investors still have limited access to investing in Saudi shares. The 2009 ROSC does note that there remains an on-going domestic debate on whether to further liberalise the market. Some of the largest companies in Saudi Arabia are not listed because the abundant liquidity in the market, along with well-capitalised banks, reduces the incentive to go public.

The ROSC also states that ownership tends to be concentrated in government and founding family holdings. In 2009, investor protection in Saudi Arabia was higher than the average achieved by OECD member states and well above the regional mean, as noted in the International Bank for Reconstruction and Development and the World Bank's (IBRD/WB) 2010 Doing Business Report. The IBRD/WB ranked Saudi Arabia on the Investor Protection Index, which is a subcomponent of the IBRD/WB 2010 Doing Business Indicators and consists of three dimensions of investor protection: transparency of transactions (Extent of Disclosure Index), liability for self-dealing (Extent of Director Liability Index) and shareholders' ability to sue officers and directors for misconduct (Ease of Shareholder Suits Index). ${ }^{119}$ The indices range between 0 and 10, with higher values indicating greater disclosure, liability of directors, powers of shareholders to challenge the transaction and investor protection. Saudi Arabia scored 9.0 on the Disclosure Index, compared to a regional average of 6.3 and OECD average of 5.9. The Kingdom scored 8.0 on the Director Liability Index, compared to a regional average of 4.8 and OECD average of 5.0. Finally, it scored 4.0 on the Shareholder Suits Index, compared to a regional average of 3.7 and OECD average of 6.6. ${ }^{120}$

Before looking at company law in Saudi Arabian corporate governance, the role of audit committees in the Saudi Arabian corporate sector is considered. ${ }^{121}$

\section{Role of Environmental Matters and Auditing in Corporate Governance}

Corporate governance practices are determined by regulations and assessed by auditing practices and environmental requirements. When considering the case of SITC, Aynain points out that Ministerial Decisions should address a lack of transparency in sensitive financial and market issues, holding accountable those who cause shareholders losses and consider the precedent of publishing the findings of decisions concerning the liquidation of listed companies in the capital market. ${ }^{122}$ Aynain claims that shareholders are eager to learn whether, when a company's assets are liquidated, shareholders' funds will be returned. Investors who bought their shares in the trading market at high prices are particularly concerned.

Aynain shows that the book value of the shares amounted to SR9 and that equity fell to SR900 million. When calculating the value of shares issued according to the price of the last closing share of SR24.30, it is clear that the market value of those shares was in the range of SR2430 million. This gives a distorted picture of the market. The value of stock in companies accused of offences of incorporation rose to record levels, while the value of shares of some companies sat near their nominal prices. ${ }^{123}$

Moreover, Aynain shows that the SITC crisis revealed serious errors in the administrative organisation and the relationship between the ministries and bodies concerned. The multiple sources charged with issuing permits

\footnotetext{
118 WB (n 85) 2-3.

119 Word Bank Group, 'Protecting Minority Investors' <http://www.doingbusiness.org/data/exploretopics/protecting-investors $>$ accessed 28 April 2013.

120 ibid.

121 J Maati, Le Government Enterprise (De Boeck University 1999).

122 Aynain (n 186).

${ }^{123}$ Aynain (n 186).
} 
allowed errors to happen. The case of the SITC is linked to three such sources: the Ministry of Commerce, the Communications Authority and the Markets Authority. ${ }^{124}$

The SITC crisis also exposed the mechanism for applying the criteria for establishing companies along with other disparities in the official bodies of company founders. In addition, Aynain highlights the transparency of government ministries and agencies alongside the Financial Market Authority. ${ }^{125}$

He stresses that the repeated errors committed in the capital market adversely affected the Kingdom's credit status, which became less than receivable. The main cause of this classification was the weakness of the capital market. He also points to specialised company classifications which seemed to be exposed after the SITC crisis. Aynain states that legal consequences continue after the decision for liquidation. The matter does not end at this point, especially if the available funds do not fulfil shareholders' rights and the responsibilities of the company's founding shareholders. ${ }^{126}$

Aynain stresses that the CMA is responsible for tracking restrictions on selling company shares in order to avoid disasters. The agency also seeks to find market manipulators and to force them to settle accounts. Restrictions imposed by the CMA may not be concealed. In the face of these developments, Aynain calls for the CMA to review its weak enforcement, to revise allowances and to tighten the criteria for inclusion in a manner that preserves the rights of investors and traders and restores lost market confidence. In respect of this, the issuance of permits should be performed by a comprehensive service centre in order to ensure that those who issue a statement are responsible for its consequences even though many actors are involved in the formation of the final declaration. ${ }^{127}$

As a result, the decision made in the case of SITC did not satisfy legal experts. Alanfa indicates that the financial market system demanded that matters be made public when publications included incorrect data about substantial matters or failed to mention substantial facts. Those who purchase securities subject to these publications are entitled to compensation for harm caused by it. Such statements or omissions are substantial if the evidence presented to the committee settling securities disputes indicates that the investor knew the impact on the price that he bought it. ${ }^{128}$

Shareholders must study the reasons for the withdrawal of a licence and deliberate whether their rights have been violated. They may bring a case against the responsible parties, whether company officers or others, if specific mistakes caused the withdrawal. These cases are a real test of the application of the corporate governance systems and bylaws protection of shareholders' rights. These cases are an indicator of the level of shareholders and investors' confidence in the Saudi market and the reputation of companies in the Kingdom. ${ }^{129}$

Alanfa points to Aynain's opinion that the matter does not end at this point. ${ }^{130}$ Stakeholders might bring the matter to judicial courts because of the loss they incurred due to the decision. Aynain emphasises the CMA's weakness and inability to ask companies about transactions, allowances and stricter criteria for trading shares. The whole matter indicates the lack of supervision and commercial regulations necessary for the CMA to monitor companies' activities and take timely actions. ${ }^{131}$

This discussion leads to that analysis of auditing and environmental issues. One can successfully link auditing and environmental practices when corporate governance practices are at a reasonable level. In this context, Chiang emphasises the comparative perspective for investigating and analysing the development of internal audit departments in Saudi Arabia. ${ }^{132}$

\section{Role of Sharia Law in the Business Environment}

Under the absolute Saudi monarchy, Sharia law forms the foundation upon which Royal Decrees are based. Sharia law is a collection of principles derived from several sources, principal among them is the Holy Quran

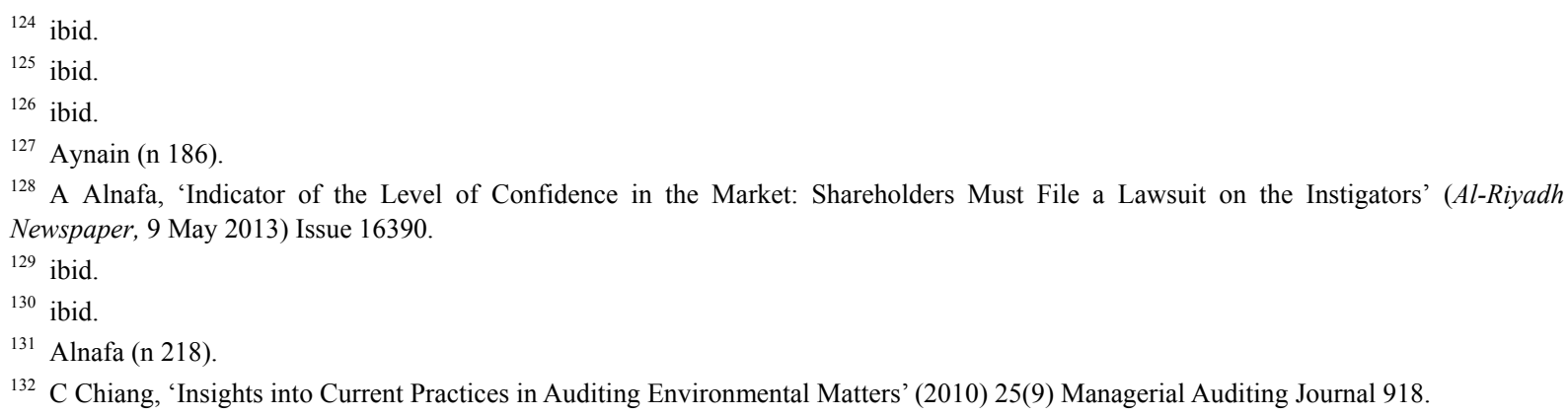


and the Sunna. Most Saudi regulations are interpreted consistently with the law of Islam.

Generally, Saudi law follows the Hanbali School of Islamic jurisprudence, which has majority and minority views on a number of issues, and bases its approach to legal construction on justice and fairness. Other Sharia principles contrary to Western business practices are the prohibitions of riba (interest) and gharar (uncertainty) and the lack of an irrevocable power of attorney. ${ }^{133}$

Islamic law is concerned with the relationship between humans and God as defined and understood by Islamic theology. Implicit in this theological relationship are dual levels of responsibility: firstly, responsibility between an individual and God; and secondly, the relationship between an individual and other humans. ${ }^{134}$ While ibadat - meaning worship - relates to the first, muamalat - or interactions-relates to the second. Anthropologically, it is necessary for Western and non-Muslim readers to understand the importance of these notions to those involved in the Saudi business context. ${ }^{135}$ One cannot separate the concept of accountability in business from the concept of accountability in the Quran, between a person and others and between a person and his God. ${ }^{136}$ The main belief of Muslims is that all creatures will be held accountable and judged for their deeds on Doomsday. Such a belief makes believers keen to do the right things and avoid the bad ones as defined by Sharia. ${ }^{137}$

Under Islam, disclosure should include all information on legal and illegal activities, employee policy, resource use and environment, and this is associated with principles such as vice-regency and justice. ${ }^{138}$ Based on the concept of accountability, it is necessary to disclose this information even when it conflicts with the company's interests. ${ }^{139}$ Ultimately, human beings are not the owners of their surroundings but are only 'vice-regents' entrusted by God with the responsibility for such things as family, property, resources and businesses.

Therefore, humans must be honest and should use property and resources according to Sharia law and Allah's will. In this way, they can fulfil their accountability to Allah. In Islam, the principle objective of accounting is to be accountable to Allah. This differs from the business accountability perspective in Western countries which gives stakeholders and owners priority. ${ }^{140}$ A business owner or manager must follow Sharia law in all transactions, including avoiding dealing with interest when borrowing or lending and reporting any activities that are not compatible with Sharia law. ${ }^{141}$ The Quran mentions the prohibition of interest several times and emphasises that Islamic law does not allow it. ${ }^{142}$

For many, there is no ambiguity in the accountability demanded in Islamic culture and business, and thus, in Saudi culture and business. Sharia instructions apply to all activities of Muslims, whether managers, shareholders or employees. ${ }^{143}$

\section{Summary}

This articel has examined the Saudi legal system for the capital market and has given the historical background of the country and the Basic Governance Law. The current practices of and improvements to the Saudi corporate governance framework and regulations have been analysed. In addition, the application of the Sharia concept of accountability in the Saudi business environment has been described. This lengthy chapter provides a detailed analysis of the current practices and the improvement of the corporate governance framework in Saudi Arabia. Background knowledge of Saudi Arabia's legal structure and its development throughout the years is very important in understanding the growth of corporate governance to the present. The foundations of Saudi Arabia's legal structure are based on Islam, and the tenets of the religion fuels corporate governance. However, there are

\footnotetext{
133 AME Info Services, 'A Guide to Doing Business in Saudi Arabia: Sharia' (18 October 2012) $<$ http://www.ameinfo.com/guide-doing-business-saudi-arabia-sharia-314267> accessed 15 July 2013.

134 ibid; U Uddin and M Tsamenyi, Corporate Governance in Less Developed and Emerging Economies (Emerald Group Publishing 2008) 189-209.

${ }^{135}$ Quran, Surat Youse, Ayah 19.

${ }^{136}$ Najwa Mordhah, 'Self-Accountability: The link between Self-Accountability and Accountability in Islam' (2012) 2(5) IJHSS $240-244$.

137 ibid 241-243.

${ }^{138}$ S Myers, 'Capital Structure' (2001) 15(2) JEP 81.

139 V Pina, L Torres and S Royo, 'Are ICTs Improving Transparency and Accountability in the EU Regional and Local Governments? An Empirical Study' (2007) 85(2) Public Administration 449.

140 Baker Alserhan, 'The Principles of Islamic Marketing' (United Arab Emirates University 1999) UAE.

${ }^{141}$ Z Iqbal and A Mirakhar, An Introduction Islamic Finance: Theory and Practice (2nd edn, John Wiley \& Sons (Asia) 2011)

${ }^{142}$ Quran, Surat 'Āli 'Imrān Iuah (130).

143 Myers (n 228).
} 
codified statutory laws, and four sets of laws laid out by the monarch have been instrumental in the creation and development of the corporate governance in the country. The Basic Law of Governance, Regional Law, Council of Ministers law and the Consultative Law are the four statutory laws that were codified in 1992. Further, the country's CMA ratified a number of changes and established a set of corporate governance regulations which was developed to be in tandem with international standards. This chapter has described the institutional infrastructure that supports the corporate governance framework in Saudi Arabia. The government agencies and institutions charged with the oversight and regulation of corporate activities to ensure compliance with corporate governance principles have been identified: the CMA, with its General Department of Corporate Governance; the CRSD, under which are the Securities Disputes Committee and the Securities Conflict Appeal Committee; the SSE; the Ministry of Commerce and Industry; and accounting and auditing professions regulated by the SOCPA. Finally, the Saudi ownership structure has been highlighted.

Furthermore, the chapter has introduced the CMA; its core functions in lieu of corporate governance; and its functions and other roles within the public sector. Further, the chapter engages in a deep discussion and exploration of institutional corporate governance structure, of both public and private institutions. Within the body of the chapter, the stock exchange becomes an important item of discussion with respect to corporate governance as well as an avenue for retribution in case of malpractice and issues that go against good and ethical corporate governance. Finally, the chapter provides a raft of comparisons on corporate governance practices in other parts of the world in relation to present corporate practice in Saudi Arabia. 